DOI: https://doi.org/10.24127/ajpm.v10i1.3258

\title{
INTERNALIZATION PROCESS OF REASONING AND PROOF STANDARDS FOR ELEMENTARY SCHOOL TEACHERS IN MATHEMATICS LEARNING
}

\author{
Awal Nur Kholifatur Rosyidah ${ }^{1}$, Umar $^{2}$, Iva Nurmawanti ${ }^{3}$, \\ Vivi Rachmatul Hidayati ${ }^{*}$, Mohammad Archi Maulyda ${ }^{5}$ \\ 1,2,3,4*,5 Pendidikan Guru Sekolah Dasar, Universitas Mataram, NTB, Indonesia \\ *Corresponding author. \\ E-mail: $\quad$ awal_rosyidah@unram.ac.id ${ }^{1)}$ \\ umarelmubaraq90@unram.ac.id ${ }^{2)}$ \\ ivanurmawanti@unram.ac.id $^{3}$ \\ vivirachma@unram.ac.id ${ }^{4 *}$ \\ archimaulyda@unram.ac.id $^{5)}$
}

Received 20 November 2020; Received in revised form 14 March 2021; Accepted 15 April 2021

\begin{abstract}
So far, students' ability in reasoning and proof has not been the concern of teachers. Many students have difficulty solving complex problems because they are not used to reasoning to solve mathematical problems. The purpose of this study is to provide a description related to the internalization of Reasoning and Proof standards in the mathematics learning process in elementary schools. The type of research used is qualitative with descriptive analysis. The research subjects were 24 elementary school teachers in Cluster IV Mataram City. The data collection process was carried out by a survey method that was conducted online using the Google form platform. To strengthen the results of the questionnaire, interviews were also conducted via WhatsApp phone to each research subject. The results of the research showed that $45.8 \%$ (11 subjects) had never heard of the terms reasoning and proof, while 54.2\% (13 subjects) had never heard of the terms reasoning and proof. The deepening of the results of this study found that the feasibility of Reasoning and Proof standards in learning was still not optimal. In addition, several interesting facts were found related to the method of proof that teachers often use, namely giving examples that are close to students (relate). The results of this study have an impact on the growth of teacher awareness to develop reasoning and evidentiary abilities in students
\end{abstract}

Keywords: Elementary school teachers; NCTM; problem based learning; reasoning and proof.

\begin{abstract}
Abstrak
Selama ini kemampuan siswa dalam penalaran dan pembuktian tidak menjadi perhatian para guru. Banyak siswa yang kesulitan menyelsaiakan masalah-masalah yang kompleks karena tidak terbiasa bernalar untuk menyelesaikan masalah matematis. Tujuan dari penelitian ini adalah untuk memberikan deskripsi terkait internalisasi standar Reasoning and Proof dalam proses pembelajaran matematika di Sekolah Dasar. Jenis penelitian yang digunakan adalah kualitatif dengan analisis deskriptif. Subjek penelitian adalah 24 guru SD di Gugus IV Kota Mataram. Proses pengumpulan data dilakukan dengan metode survey yang dilakukan secara online menggunakan platform Google form. Untuk memperkuat hasil angket, juga dilakukan wawancara melalui whatsapp phone kepada masing-masing subjek penelitian. Hasil penelitan menunjukkan bahwa 45,8\% (11 subjek) belum pernah mendengar istilah reasoning and proof, sedangkan 54,2\% lainya (13 subjek) pernah mendengar istilah reasoning and proof. Pendalaman hasil penelitian ini menemukan bahwa keterlaksaan standar Reasoning and Proof dalam pembelajaran masih belum optimal. Selain itu juga ditemukan beberapa fakta menarik terkait dengan metode pembuktian yang sering digunakan guru adalah pemberian contohcontoh yang dekat dengan siswa (relate). Hasil penelitian ini memberikan dampak pada tumbuhnya kesadaran guru untuk mengembangkan kemampuan penalaran dan pembuktian pada siswa.
\end{abstract}

Kata kunci: Guru SD; NCTM; problem based learning; reasoning and proof.

This is an open access article under the Creative Commons Attribution 4.0 International License 
DOI: https://doi.org/10.24127/ajpm.v10i1.3258

\section{INTRODUCTION}

The National Council of Teachers of Mathematics as the world's mathematics teacher organization has formulated five basic ability standards that a person must have in the mathematics learning process (NCTM, 2000). The five standards are (1) Problem Solving; (2) Reasoning and Proof; (3) Mathematical Connection; (4) Mathematical Communication; dan (5) Mathematical Representation (Maulyda, 2020). In its implementation, NCTM has described several indicators and examples of detailed learning at each level of education (by age). According to Hekimoglu \& Sloan (2015), The most difficult implementation of NCTM standards is at the basic education level (ages 6-11 years). This is because the introduction of a very abstract mathematical concept will contradict the cognitive abilities of elementary school students who are still in concrete phase (King, 2014). Therefore, NCTM tries to construct as simple as possible learning to suit the cognitive level of students. The examples of learning provided by NCTM for basic education are quite concrete. However, in fact, it is still difficult for elementary teachers to implement NCTM standards (Metz, 2010). The difficulty of elementary school teachers in implementing NCTM standards is also suspected because students and teachers are more "fond" of implementing conventional (teachercentered) learning. In fact, based on NCTM standards, the paradigm used is student-centered type of learning. This contrasting paradigm makes it difficult to implement NCTM standards at the basic education level (Jitendra et al., 2010).

Specifically, Wang \& Wang (2018) state that From five standards formulated by NCTM, the most difficult to implement are Reasoning and Proof. This is in line with study done by Komatsu (2016) that states Mathematical skills that are most difficult to develop in students are the ability to reason and prove. Reasoning ability requires students to draw conclusions from a statement with logical and acceptable reasons (Ko \& Knuth, 2013). "Acceptable" is not enough, Tall (2014) explain that in reasoning students must be able to prove the truth of the statement given. In this case, the author sees a factor in the application of the Problem Based Learning (PBL) which is still not optimal for teachers in elementary schools. In PBL, the construction of mathematical concepts carried out will be based on giving problems to students (Boud \& Feletti, 2013). This problembased learning that is carried out can trigger students to provide arguments that can have an impact on students' reasoning and proof abilities. (Reasoning and Proof) (Okubo et al., 2012).

To strengthen this statement, authors conducted a preliminary research study to explore information related to PBL in Elementary School. The author gave a questionnaire to 24 elementary school teachers in Cluster IV Mataram City. Following are the results of the initial research: studies in Figure 1.

Based on the results of the preliminary research conducted, it appears that only 2 teachers have ever used the PBL model more than 10 times. Then there were 8 teachers who used the PBL model less than 10 times. Meanwhile, the other 14 teachers never did PBL in learning process. These results are in line with the research conducted by Filipenko \& Naslund 
(2015) where teachers in schools still experience confusion in PBL. Teachers are not accustomed to constructing mathematical concepts that depart from problems so that teachers rarely use this model. Besides, according to Diani et al. (2018) PBL also requires teachers and students to have a good number sense in order to analyze a problem. This ability is rarely possessed by teachers at the basic education level.

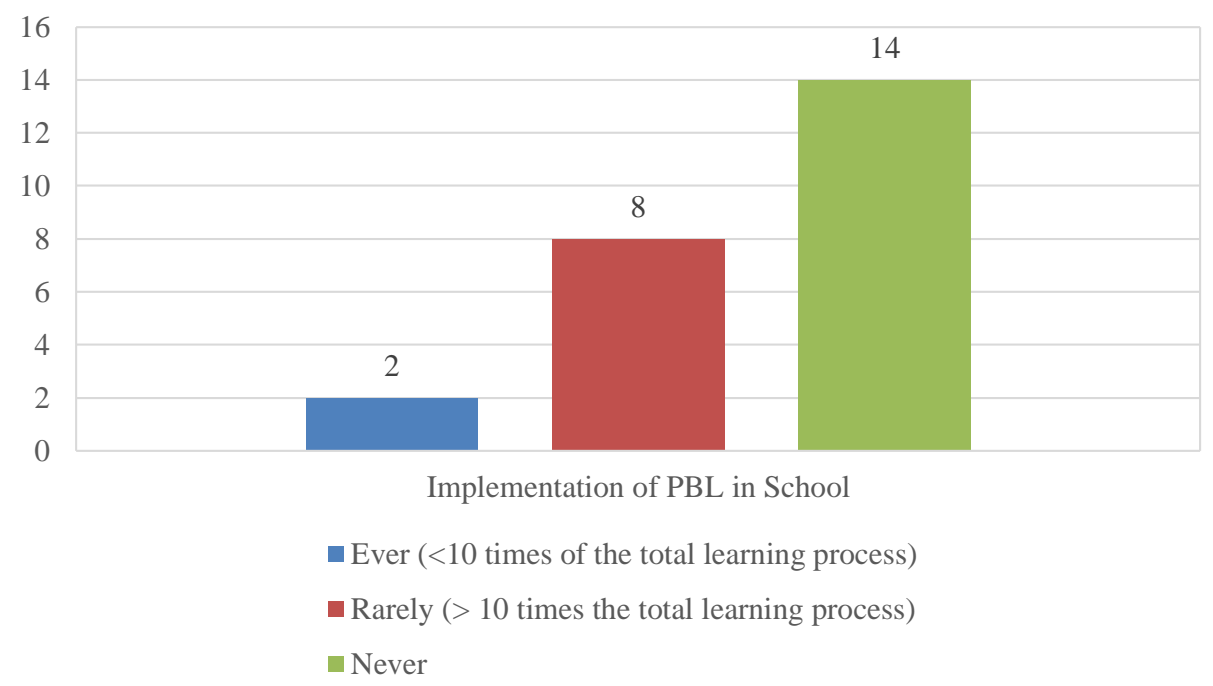

Source: Research Data

Figure 1. Preliminary research result.

In this study, authors will focus on the exposure of mathematics learning management by teachers towards Reasoning and Proof standards. Research related to the ability to reason and prove by students has been done a lot. Like research conducted by Hidayati \& Widodo (2015) which states that students' ability to reason is low as a result of students not being accustomed to being given non-routine questions. In addition, there are also research results by cccc which describes the process of reasoning and proof failure that occurs in students, where the failure that occurs is at the conjecture / hypothesis formulation stage. Based on the results of preliminary studies and literature reviews conducted, authors suspect that the reason for the difficulty in developing reasoning skills and prove this is because the management of mathematics learning according to
Reasoning and Proof standards is still not optimal.

PBL learning activities are one way to train students in developing their Reasoning and Proofing abilities. The problem-based learning process can require students to prove the assumptions and hypotheses they have when solving a given problem. However, many teachers do not realize this. Many teachers only use PBL as a teaching tool, not to use it in developing students' Reasoning and Proofing abilities.

Therefore, this study aims to describe the process of internalizing the standard of Reasoning and Proof of mathematics learning in PBL model. Specifically, authors will look at the internalization process at the primary education level with the teacher as the main subject. Authors hope that the research results can become a treasure 
DOI: https://doi.org/10.24127/ajpm.v10i1.3258

of insights related to the difficulty of implementing NCTM learning, especially in the Reasoning and Proof standard.

\section{METHOD}

To achieve the research objectives, authors used a qualitativedescriptive research approach. Based on Creswell (2014), qualitative research can provide a real and factual figure of a phenomenon. The research subjects were 24 elementary school teachers in Cluster IV Mataram City. The selection of research subjects was based on the following criteria: (1) The teacher must have 7 years of teaching experience (since the 2013 curriculum was issued); (2) The teacher should teach higher grade of elementary school students (Class IV, V \& VI); and (3) The teacher is willing to be a subject in the research.

The instrument used in this research is a google form survey which will be distributed to the research subjects online. The research instrument was evaluated by 3 experts consisting of all relevant stakeholders. The instrument has been measured and got a good category and is suitable for use from expert validators consisting of 2 lecturers and 1 teacher. The second instrument is a guideline for interviews conducted via WhatsApp. The purpose of conducting interviews is to strengthen the survey answers given online previously.

The use of online platform is because of the authors consider the health protocol of Covid-19. The first step is asking the research subject to fill out a survey given by Google form link. Subjects who filled out the survey were then interviewed by WhatsApp (by chat or calls) regarding the completed survey results. Furthermore, the results of the survey and interview were analyzed descriptively using the Reasoning \& Proof indicator as follows Table 1.

Table 1. Reasoning and proof - based learning implementation indicators adapted from indicators Komatsu (2016)

\begin{tabular}{|c|c|c|}
\hline Indicators & Indicators Description & Code \\
\hline Conducting validation & $\begin{array}{l}\text { - Teachers provide problems that are related to the } \\
\text { students' daily life } \\
\text { - The teacher invites students to observe the } \\
\text { problems given }\end{array}$ & B1 \\
\hline $\begin{array}{l}\text { Formulating } \\
\text { conjecture }\end{array}$ & $\begin{array}{l}\text { - Teachers provide opportunities for students to } \\
\text { express their opinion } \\
\text { - The teacher asks students to make hypotheses } \\
\text { (statements) which the students think are true }\end{array}$ & B2 \\
\hline $\begin{array}{l}\text { Making deduction } \\
\text { statement }\end{array}$ & $\begin{array}{l}\text { - The teacher provides the opportunity for other } \\
\text { students to comment on students' arguments (give } \\
\text { each other comments) }\end{array}$ & B3 \\
\hline $\begin{array}{l}\text { Justifying the } \\
\text { statement }\end{array}$ & $\begin{array}{l}\text { - The teacher directs students to make reasons and } \\
\text { scientific evidence to validate students' statements }\end{array}$ & B4 \\
\hline Exploring result & $\begin{array}{l}\text { - The teacher encourages students to check the } \\
\text { accuracy of evidence and its real value } \\
\text { - The teacher encourages students to connect the } \\
\text { results of the evidence with everyday life }\end{array}$ & B5 \\
\hline
\end{tabular}


DOI: https://doi.org/10.24127/ajpm.v10i1.3258

The data analysis technique used in qualitative analysis has four stages, namely data collection, data reduction, data presentation and the last step is drawing conclusions and verification. In this study, the data obtained from the questionnaire were reduced in categories. This category is based on steps of reasoning and evidentiary indicators. In addition, researchers will also provide explanations related to the relationship between the reasoning and evidentiary processes with the PBL learning process that has been carried out by teachers. The results of this analysis will then be used as a basis for drawing conclusions.

\section{RESULTS AND DISCUSSION}

Thompson et al. (2012) said the ability of reasoning and proof is an important part of mathematics. The aspect of reasoning and proof is an aspect of NCTM that focuses on students' ability to think critically (NCTM, 2009). However, in fact, from 24 research subjects, $45.8 \% \quad(11$ subjects) had never heard of the terms reasoning and proof. Meanwhile, another $54.2 \%$ (13 subjects) had heard the terms reasoning and proof. This can be seen in the questionnaire result data in Figure 2.

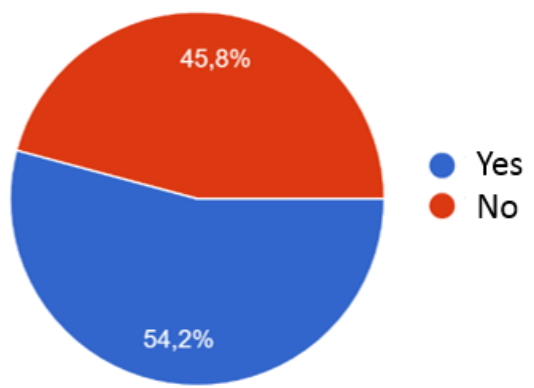

Figure 2. Percentage of subjects who have heard the terms reasoning and proof
In the Figure 2, it can be seen that more than $50 \%$ of research subjects have heard the term reasoning and proof. Interestingly, when asked about the definition of reasoning and proof, only 2 research subjects could explain the definitions of reasoning and proof well. This shows that most likely, the research subject has carried out a learning process based on reasoning and proof without knowing the definition of this reasoning and proof aspect. This is in line with the research conducted by Simon (2020) that most teachers who teach in schools do not think about theoretical things such as models, strategies, or learning approaches, but actually have used them in classroom learning. This is further strengthened by Hafid (2011) that practitioners tend not to focus too much on theory but use experience as a learning resources. To clarify the appropriateness of the reasoning and proof indicators in learning, each of the following indicators will be discussed.

\section{a. Conducting Validation (B1)}

Based on the results of the research, the implementation this indicator in learning process can be seen in Figure 3.

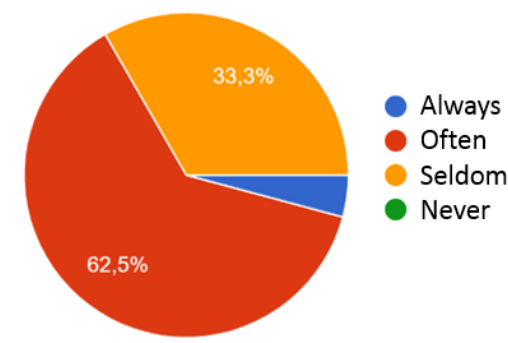

Figure 3. Implementation of "conducting validation" indicator

The operational form of the indicator B1 in classroom is the activity of observing problems / mathematical statements by students. Figure 3 shows that $62.5 \% \quad(15$ subjects $)$ often 
encouraged students to observe a mathematics problem in class. Meanwhile, $33.3 \%$ (8 subjects) rarely carried out the activity of observing this problem. The remaining $4.2 \% \quad(1$ subject) always invites students to do this activity. Based on Navarro et al. (2016), the activity of observing problems can train students' ability to think critically. Because of this critical thinking process, students will crosscheck a statement. In this process, students will dig up information, both internal and external, to ensure their argument is a problem (Bikić et al., 2016). Related to this, the research results from Kovach \& Montgomery (2010) shows that the observation activities carried out by students will form the character of critical thinking in students. This shows that it is important for teachers to carry out observation activities on this problem in the learning process.

\section{b. Formulating Conjecture (B2)}

The second indicator in the reasoning and proof activity is to formulate a conjecture or better known as a hypothesis (guesswork). This activity is an activity to analyze a problem or a statement, then we can position our side of the problem (Berland \& McNeill, 2010). However, our guess at this stage is still subjective because it is only based on the information and intuition we have. According to Hunt et al. (2013) NCTM includes this activity in reasoning, because in making an assumption, a person will dig up information that he previously had. Extracting this information is one of the stages of reasoning according to (Hidayati \& Widodo, 2015). In this regard, the implementation of the indicator B2 in Cluster IV Mataram City is quite good. This can be seen in Figure 4 .

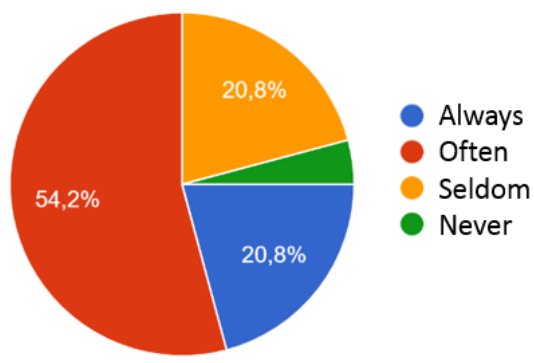

Figure 4. Implementation of

"formulating conjectures" indicator

In the Figure above, it can be seen that from 24 research subjects, 54.2\% (13 subjects) often provide opportunities for students to analyze problems and propose hypotheses. Meanwhile, 20.8\% (5 subjects) rarely asked students to make hypotheses. According to McNeill \& Knight (2013) making statements, expressing opinions, or making assumptions can stimulate students' creative thinking ability. This activity will familiarize students with finding solutions and possibilities for a problem. Regardless of whether the statement is true or false, students' creativity will be formed through the activity of proposing the hypothesis (Manz, 2015). Because it is important for teachers in schools to start encouraging students to make statements or hypotheses more often. Based on the results of interviews conducted with subjects, the following methods are often used by teachers when they want to encourage students to make hypotheses.

In Figure 5, it can be seen that the method used by almost all teachers is to ask inducement questions. All subjects chose this method when they wanted to invite students to make hypotheses. Not less than 20 research subjects allow students to find new information to support their hypothesis both from books and from the internet. These results are in line with the results of the 
DOI: https://doi.org/10.24127/ajpm.v10i1.3258

research conducted Sampson \& Blanchard (2012) that students will find it easier to provide opinions or statements when provoked by directive questions by the teacher. Besides that, according to Koehler et al. (2014) This kind of thing also shows the depth of material possessed by the teacher. The better the inducement questions given, the better the results of the arguments given by the students.

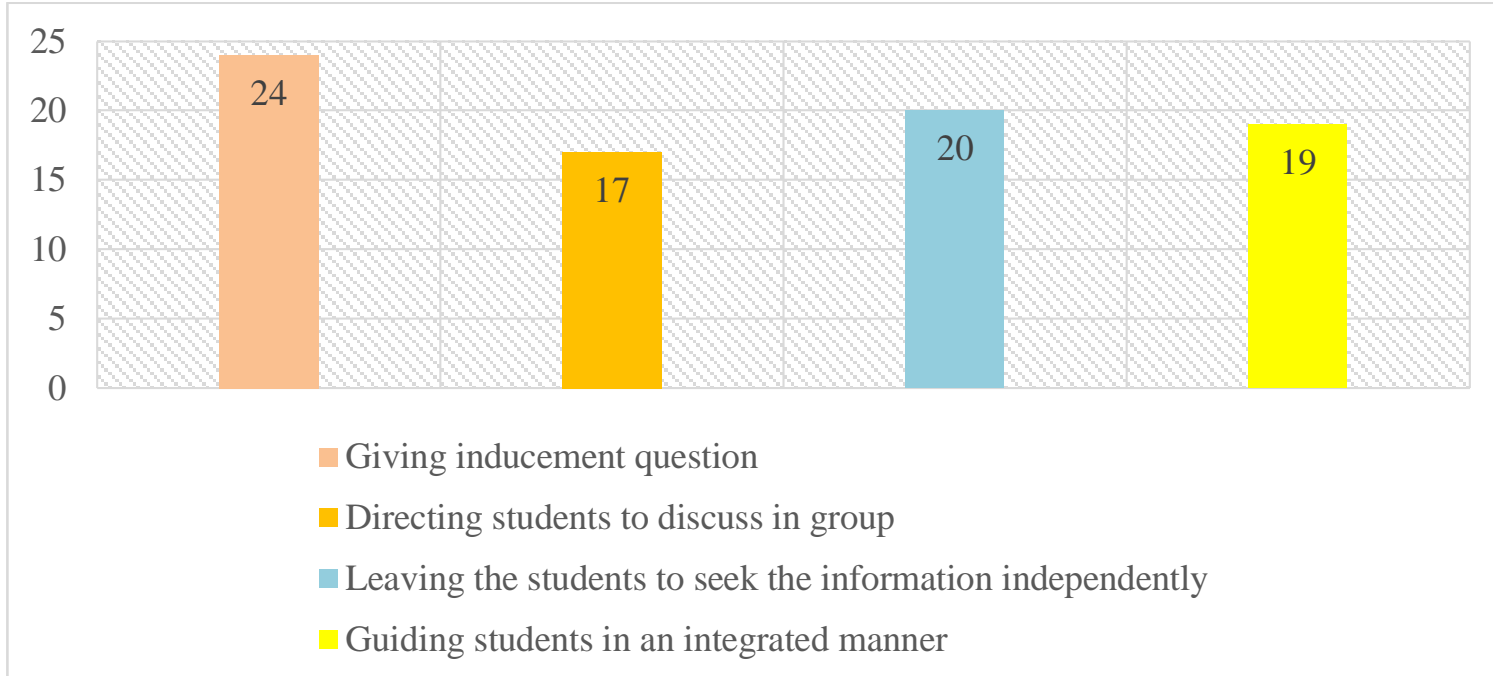

Figure 5. The method used by the subject in exploring students' hypotheses

\section{c. Making deduction statement (B3)}

The implementation of indicator

B3 is very high, that is $100 \%$. This means that teachers have provided opportunities for students to comment on each other's theme arguments. According to Faradillah (2018) In formulating an accurate hypothesis, new information is needed to compare our expectations. Indirectly, the direction of our hypothesis formulation will be more specific (special). If initially the students' hypotheses are still general, and tend to be superficial, with comments from friends, this new information will be processed into more specific and in-depth hypotheses. According to Komatsu (2016) It is important for the teacher to provide reinforcement or additional information to students so that they can deepen the hypothesis they made.

\section{d. Justifying the Statement (B4)}

At this stage, students will be invited to prove whether the initial statement or hypothesis made is true or false. The implementation of the indicator B4 is the same as the indicator $\mathrm{B} 3$, which is $100 \%$, meaning that the twenty-four research subjects have encouraged students to prove the statement previously made. In addition to the teacher who provides justification, the students can also provide justification for each other's statement. According to Lo et al. (2008) students will more easily accept the justification given by their peers. This is influenced by the pattern of communication between children of the same age which tends to be similar and this makes it easier for children who are of the same age to understand each other (Mizumoto et al., 2019). Interesting things were found when the subject was asked regarding the method 
DOI: https://doi.org/10.24127/ajpm.v10i1.3258

of proof used in the classroom. The following are the choice of proving method chosen by the teacher, which are described in Figure 6.

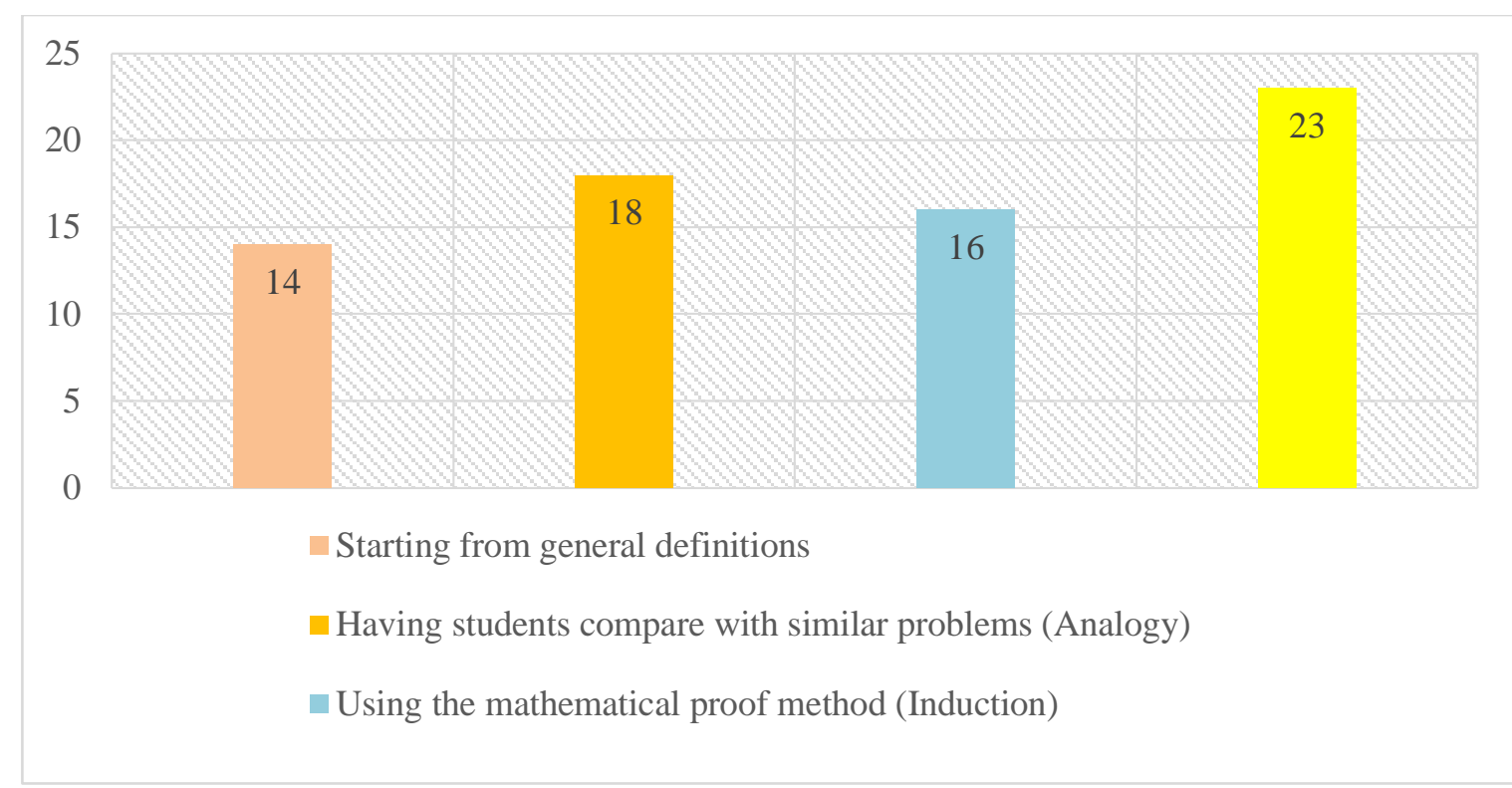

Figure 6. Proof method that is chosen by subject.

Figure 6 shows that the method of proof most used by subjects is the "relation method", which is as many as 19 subjects. Meanwhile, in the second position is the analogy method chosen by 18 research subjects. This is interesting considering the results of the studies conducted Zhao et al. (2020) produce data that students prefer to use the generalization method in proving their hypothesis. This is because this method consists of general matters, such as definitions in student textbooks. In addition, based on the results of the research conducted by Fahle (2005) on 56 teachers in Texas showed that teachers prefer to use the generalization method, this will provoke students to construct their own justification without teacher assistance. By choosing the analogy and relation method, it shows that the research subject still has a share in the process of evidence carried out by students.

\section{e. Exploring Result (B5)}

The last stage in the reasoning and proof learning activity is to explore the results or develop conclusions. The implementation of indicator B5 can be seen in Figure 7.

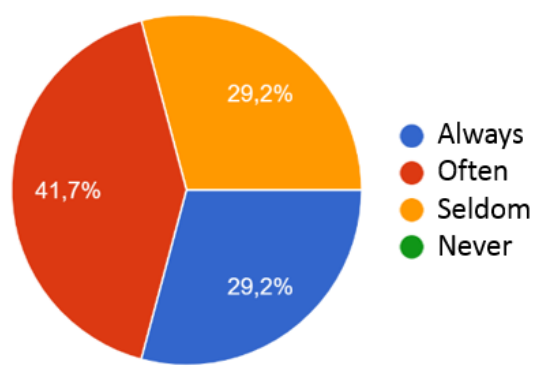

Figure 7. Implementation of exploring results indicator

Figure 7 shows that $41.7 \%$ (10 subjects) often encourage students to develop the conclusions obtained. Meanwhile, 29.2\% (subjects) rarely encourage students to develop conclusions. According to Ruggiero \& Mong (2015) the development of learning can be realized by the formation of a connection between a 
mathematics topics/concepts and the students' daily life. Toom et al. (2015) argues that this kind of extension can also take the form of useful-related information about what was learned with problems previously seen as unrelated to one another. Expanding the results of the conclusions will also train students not to stop at one possible outcome, but to dig deeper to find other possible information that might be obtained.

\section{CONCLUSION AND SUGESSTION}

There are more than $50 \%$ of teachers who are familiar with the terms reasoning and proof. Even so, there are 2 teachers who can explain the meaning of reasoning and proof correctly. The implementation of the indicators on reasoning and proof in learning is seen to be quite good. As many as 15 out of 24 teachers often implement conducting validation indicators in learning. The teacher also provides reinforcement on the formulating conjecture indicators in this lesson. The teacher is giving inducement questions; having group discussion; leaving students study independently; and guiding students properly to reinforce this indicator in learning activities. It was recorded that all the teachers applied the making deduction statement indicator. The teacher facilitates students to give opinions or comments on their friends' results. All teachers then implemented the justifying the statement indicator in learning. Students are asked to prove hypotheses made in ways such as starting from general definition; thinking analogy; and mathematical proofing. A total of 17 teachers encourage students to conclude the results obtained; check the correctness of the conclusions; as well as connecting with real life contexts.
For further research, researchers should begin to explore students' reasoning abilities by providing problem-solving questions. Student work results data will be able to provide a more concrete picture related to students' reasoning and proof abilities. In addition, through giving questions, the results of the PBL learning process will also be seen on students' reasoning and proof abilities.

\section{REFERENCES}

Berland, L. K., \& McNeill, K. L. (2010). A learning progression for scientific argumentation: Understanding student work and designing supportive instructional contexts. Science Education, 3(3), 67-78. https://doi.org/10.1002/sce.20402

Bikić, N., Maričić, S. M., \& Pikula, M. (2016). The effects of differentiation of content in problem-solving in learning geometry in secondary school. Eurasia Journal of Mathematics, Science and Technology Education, 5(2), 15-23. https://doi.org/10.12973/eurasia.2 016.02304a

Boud, D., \& Feletti, G. I. (2013). The challenge of problem-based learning. In The Challenge of Problem-based Learning (1st ed.). Berrett Koehler Inc. https://doi.org/10.4324/978131504 2039

Creswell, J. W. (2014). Research Design: Qualitative, Quantitative and Mixed Methods Approaches (4th ed.). SAGE.

Diani, R., Yuberti, Y., \& Syarlisjiswan, M. R. (2018). Web-Enhanced Course Based on Problem-Based Learning (PBL): Development of Interactive Learning Media for 
Basic Physics II. Jurnal Ilmiah Pendidikan Fisika Al-Biruni, 7(1), 105.

https://doi.org/10.24042/jipfalbiru ni.v7i1.2849

Fahle, M. (2005). Perceptual learning: Specificity versus generalization. In Current Opinion in Neurobiology.

https://doi.org/10.1016/j.conb.200 5.03.010

Faradillah, A. (2018). Analysis of Mathematical Reasoning Ability of Pre-Service Mathematics Teachers in Solving Algebra Problem Based on Reflective and Impulsive Cognitive Style. Formatif: Jurnal Ilmiah Pendidikan MIPA, 8(2). https://doi.org/10.30998/formatif.v $8 \mathrm{i} 2.2333$

Filipenko, M., \& Naslund, J. A. (2015). Problem-based learning in teacher education. In Problem-Based Learning in Teacher Education. Macmillan Publishing Co., Inc. https://doi.org/10.1007/978-3-31902003-7

Hafid, H. A. (2011). Sumber dan Media Pembelajaran. Jurnal Sulesana, 1(3), 56-78.

Hekimoglu, S., \& Sloan, M. (2015). A Compendium of Views on the NCTM Standards. Mathematics Educator, 15(1), 35-43.

Hidayati, A., \& Widodo, S. (2015). Proses Penalaran Matematis Siswa dalam Memecahkan Masalah Matematika pada Materi Pokok Dimensi Tiga Berdasarkan Kemampuan Siswa di SMA Negeri 5 Kediri. Jurnal Math Educator Nusantara, 7(3), 45-68.

Hunt, T., Carper, J., Lasley, T., Raisch, C., \& Dickey, E. M. (2013). National Council of Teachers of Mathematics. In Encyclopedia of
Educational Reform and Dissent. University of Illinois. https://doi.org/10.4135/978141295 7403.n297

Jeannotte, D., \& Kieran, C. (2017). A conceptual model of mathematical reasoning for school mathematics. Educational Studies in Mathematics, 35(4), 235-267. https://doi.org/10.1007/s10649017-9761-8

Jitendra, A. K., Griffin, C. C., \& Xin, Y. P. (2010). An Evaluation of the Intended and Implemented Curricula's Adherence to the NCTM Standards on the Mathematics Achievement of Third Grade Students: A Case Study. Journal of Curriculum and Instruction, 7(3), 208-231. https://doi.org/10.3776/joci.2010.v 4n2p33-50

King, A. (2014). Mathematical Explorations: Freshwater Scarcity A Proportional Representation. NCTM, 20(3), 152-157.

Ko, Y. Y., \& Knuth, E. J. (2013). Validating proofs and counterexamples across content domains: Practices of importance for mathematics majors. Journal of Mathematical Behavior, 15(2), 563-678.

https://doi.org/10.1016/j.jmathb.2 012.09.003

Koehler, M. J., Mishra, P., Kereluik, K., Shin, T. S., \& Graham, C. R. (2014). The technological pedagogical content knowledge framework. In Handbook of Research on Educational Communications and Technology: Fourth Edition (2nd ed.). Berrett Koehler Inc. https://doi.org/10.1007/978-14614-3185-5_9 
Komatsu, K. (2016). A framework for proofs and refutations in school mathematics: Increasing content by deductive guessing. Educational Studies in Mathematics.

https://doi.org/10.1007/s10649015-9677-0

Kovach, M., \& Montgomery, H. (2010). What kind of learning? For what purpose? Reflections on a critical adult education approach to online Social Work and Education courses serving Indigenous distance learners. Critical Social Work, 11(May), 27-61.

Lo, J. J., Grant, T. J., \& Flowers, J. (2008). Challenges in deepening prospective teachers' understanding of multiplication through justification. Journal of Mathematics Teacher Education, 4(3), 556-578. https://doi.org/10.1007/s10857007-9056-6

Manz, E. (2015). Representing Student Argumentation as Functionally Emergent From Scientific Activity. Review of Educational Research, 14(4), 413-422. https://doi.org/10.3102/003465431 4558490

Maulyda, M. A. (2020). Paradigma Pembelajaran Matematika berbasis NCTM (1st ed., Issue January). CV. IRDH Malang.

McNeill, K. L., \& Knight, A. M. (2013). Teachers' pedagogical content knowledge of scientific argumentation: The impact of professional development on K-12 teachers. Science Education, 12(3), 45-57. https://doi.org/10.1002/sce.21081

Metz, M. L. (2010). Using GAISE and NCTM standards as frameworks for teaching probability and statistics to pre-service elementary and middle school mathematics teachers. Journal of Statistics Education, 6(4), 143-157. https://doi.org/10.1080/10691898. 2010.11889585

Mizumoto, T., Ouchi, H., Isobe, Y., Reisert, P., Nagata, R., Sekine, S., \& Inui, K. (2019). Analytic Score Prediction and Justification Identification in Automated Short Answer Scoring. Procedia Computer Science. https://doi.org/10.18653/v1/w194433

Navarro, D. J., Newell, B. R., \& Schulze, C. (2016). Learning and choosing in an uncertain world: An investigation of the exploreexploit dilemma in static and dynamic environments. Cognitive Psychology, 11(2), 14-26. https://doi.org/10.1016/j.cogpsych .2016.01.001

NCTM. (2009). Focus in High School Mathematics: Reasoning and Sense Making. In The Mathematics Teacher (2nd ed.). McGraw-Hill Education. https://doi.org/10.5951/mathteach er.106.8.0635

Okubo, Y., Ishiguro, N., Suganuma, T., Nishikawa, T., Takubo, T., Kojimahara, N., Yago, R., Nunoda, S., Sugihara, S., \& Yoshioka, T. (2012). Team-based learning, a learning strategy for clinical reasoning, in students with problem-based learning tutorial experiences. Tohoku Journal of Experimental Medicine, 12(5), 67-87. https://doi.org/10.1620/tjem.227.2 3

Ruggiero, D., \& Mong, C. J. (2015). The teacher technology integration experience: Practice and reflection 
DOI: https://doi.org/10.24127/ajpm.v10i1.3258

in the classroom. Journal of Information Technology

Education: Research, 12(4), 314325. https://doi.org/10.28945/2227

Sampson, V., \& Blanchard, M. R. (2012). Science teachers and scientific argumentation: Trends in views and practice. Journal of Research in Science Teaching, $8(3)$, 55-78. https://doi.org/10.1002/tea.21037

Simon, M. A. (2020). Reconstructing Mathematics Pedagogy from a Constructivist Perspective. Journal for Research in Mathematics Education, 25(4), 887-896.

https://doi.org/10.5951/jresemathe duc.26.2.0114

Tall, D. (2014). Making Sense of Mathematical Reasoning and Proof (2nd ed.). Fakulti Pendidikan UKM. https://doi.org/10.1007/978-94007-7473-5_13

The National Council of Teachers of Mathematics. (2000). Principles and Standards for School Mathematics. The National Council of Teachers of Mathematics, Inc.

Thompson, D. R., Senk, S. L., \& Johnson, G. J. (2012). Opportunities to learn reasoning and proof in high school mathematics textbooks. Journal for Research in Mathematics Education, 4(4), 85-98. https://doi.org/10.5951/jresemathe duc.43.3.0253
Toom, A., Husu, J., \& Patrikainen, S. (2015). Student teachers' patterns of reflection in the context of teaching practice. European Journal of Teacher Education, 7(3), 123-134. https://doi.org/10.1080/02619768. 2014.943731

Wang, Z., \& Wang, Z. (2018). Error Analysis of 8th Graders' Reasoning and Proof of Congruent Triangles in China. In Journal of Mathematics Education (Vol. 11, Issue 2). https://doi.org/10.26711/00757715 2790029

Zhao, L., Peng, X., Chen, Y., Kapadia, M., \& Metaxas, D. N. (2020). Knowledge As Priors: CrossModal Knowledge Generalization for Datasets Without Superior Knowledge. Proceedings of the International Association of Hydrological Sciences, 677. https://doi.org/10.1109/cvpr42600. 2020.00656 